\title{
Impact of the carbon cycle on mercury dynamics in a river impacted by run-of-the-river power plants, logging and forest fire
}

\author{
M. AMYOT', D. PONTON', F. BILODEAU ${ }^{2}$, M. HARRISON ${ }^{3}$, \\ M. LECLERC', L. MILLERA FERRIZ, R. LAVOIE ${ }^{4}$, V . \\ STORCK ${ }^{1}$, D. PlanAS, A.J. POULAIN ${ }^{\circ}$, D. WALSH ${ }^{3}$ \\ Dept. of Biological sciences, Univ. of Montreal, Montreal, \\ H2V 0B3, CANADA (Correspondence: \\ m.amyot@umontreal.ca) \\ ${ }_{2}^{2}$ Hydro-Québec, Dir. Environment, Montreal, H2L 4M8, \\ CANADA \\ Dept. of Biology, Concordia Univ., Montreal, CANADA \\ ${ }^{4}$ ECCC, Quebec City, G1J 0C3, CANADA \\ 'Dept. of Biological sciences, UQAM, Montreal, H2X 3 Y7 \\ CANADA \\ - Dept of Biology, Univ of Ottawa, Ottawa, K1N 6N5, \\ CANADA
}

Run-of-the-river hydroelectric power plants are thought to have little impact on $\mathrm{Hg}$ methylation and food web contamination, because they do not cause flooding of large areas. On the St. Maurice River (Canada), an unpredicted increase in $\mathrm{Hg}$ accumulation in top predators was observed after the construction of two such power plants, in the vicinity of a native community. This riverscape was also altered by a large forest fire and by logging activities. We studied this system to identify key drivers of $\mathrm{Hg}$ cycling with various approaches, including isotopic tracing for methylation/demethylation rates in sediments and periphyton, metagenomic analyses of genes related to $\mathrm{Hg}$ cycling and to metabolism of key methylating guilds, 13C and $15 \mathrm{~N}$ tracing of food web transfer, and geochemical analyses including quality of DOM and Itrax XRF scanner.

We found that the small inpoundment upstream of the power plants were sites of $\mathrm{Hg}$ and $\mathrm{MMHg}$ accumulation in sediments. There was a strong association between organic matter content and $\mathrm{Hg}$ and $\mathrm{MMHg}$ concentrations. It is likely that these reservoirs are acting as sedimentation basins for fresh organic matter originating from logging activities, and the fresh organic carbon fuels methylation. Methylation genes $(h g c A)$ were found at most sites and the number of copies was positively correlated to copies of genes linked to methanogenesis. Carbon sources (13C) modulated $\mathrm{Hg}$ accumulation at the base of the food chain whereas trophic levels $(15 \mathrm{~N})$ explained variations up to the top of the food chain. This study indicates that carbon cycling is a key driver of $\mathrm{Hg}$ dynamics in this system. 